\title{
First results concerning the energy and protein value of protein rich spring peas (Pisum sativum L.)
}

\author{
D. BOURDON, J.M. PEREZ \\ I:V.R.A., Station de Recherches sur l'Elevage des Porcs, \\ Centre de Rennes-Saint-Gilles, F 35590 L'Hermitage
}

A digestibility study was made in order to estimate the energy and protein value for growing pigs of two protein rich spring varieties of peas (Amino and Finale) including 26.4 and 24.5 p. 100 crude protein, respectively (p. 100 D.M.).

The trial was performed on 12 castrated male pigs, with a mean weight of $34.1 \mathrm{~kg}$, placed in individual cages. Excreta were collected for 10 consecutive days. The energy and protein value of the peas was estimated by the substitution method using diets containing 40 p. 100 Amino peas (group 2) or Finale peas (group 3), in replacement of a fraction of a diet based on maize-soybean meal (group 1).

According to the results of this preliminary study, the average digestible energy value of the protein rich spring peas was $3950 \mathrm{kcal}$, i.e. the same energy value as that of maize and comparable to that of winter peas $(3930 \mathrm{kcal} / \mathrm{kg}$ D.M. $)$. The digestibility of crude protein ( 87.5 p. 100) appeared to be slightly lower than that of soybean meal ( 89 p. 100).

The differences between the two samples tested in the utilization of energy (D.E./ $\mathrm{kg}$ D.M. 3801 vs 4093 ; A.D.E. : 86.8 vs 92.5 , respectively for the varieties Amino and Finale) may be explained by the different carbohydrate composition of the seeds (starch, a-galactosides).

\section{Utilization of protein rich peas by early weaned piglets Influence of the level of incorporation and of the variety}

\author{
P. QUEMERE *, J. FEKETE **, M. LEUILLET ** \\ * S.E.R.E.P., Institut supérieur agricole, F 60026 Beauvais \\ *: I.T.C.F., 8, avenue du Président-Wilson, F 75116 Paris
}

Two series of experiments were carried out in weaned piglets in order to study the influence of the level of incorporation of peas in diets based on maize (300 piglets) as well as the effect of the pea variety on its utilization (500 piglets).

All results indicate that the utilization of peas of the winter variety Frimas should be restricted. The recommendations formulated previously about that variety are thus confirmed (a maximum incorporation level of 15 p. 100).

Opposite to that, the good results obtained in piglets receiving large proportions (until 28 p. 100) of spring peas of the varieties Amino and Finale should permit to increase their levels of incorporations, probably up to 20-25 p. 100.

This difference between pea varieties may be explained, at least partly, by the low level of antitrypsine factors in spring peas. 